\title{
LEARNING STYLE OF GRADE V STUDENTS AT ELEMENTARY SCHOOLS IN BLITAR
}

\author{
Lilik Bintartik, Yuniawatika, Esti Untari \\ Faculty of Education State University of Malang \\ Campus 3 Jl.Ir Soekarno 1 of Blitar \\ lilik.bintartik.fip@um.ac.id
}

\begin{abstract}
The purpose of this study is to identify learning styles of grade V students at elementary schools in Blitar. This is a quantitative study using descriptive methods involving grade V students at elementary schools in Blitar Sample of 199 students were selected using simple random sampling. Questionnaires were used to gather the data, and analyzed employing descriptive statistical techniques. Results showed that the auditorial learning style was used dominantly by all female and male students.
\end{abstract}

Keywords: students, teachers, teaching, learning styles.

\section{INTRODUCTION}

Education is designed to develop learners' capacities. Children have different abilities. They were born having different intellectual capacities in absorbing, processing, and conveying the incoming information. Each has unique characteristics for left and right brain. The right brain has long term memory while the left one has a short term memory. Bob Samples (2002) described that (a) the function of the brain-mind as an open system; (b) modalities, intelligence, learning styles, and creativity in learning, and the ways in which they are developed; (c) the use of music, sound, relaxation, pictures, humor, and dreams to build an atmosphere of play and learn effectively and engross with children, without prejudice to the nature of learning; and (d) activities, tips, and advice that is easy to do to develop the ability to learn and access information through the entire learning modality. The ability of students in processing the incoming information depends on their learning styles as the important learning modality. This is in line with the statement of Sen (2012) that learning style is a factor that can influence students performance.

Based on these opinions can be seen that students learning styles are the important factor since they provide certain effects to the efforts in improving student learning performance. Hence, Ilmiyah (2013) suggests that teachers have to adjust the pace of the teaching learning process with students' characteristic, in particular related with the way they learn information or knowledge. Teachers and students, then, need to know what individual learning styles characterize their way in studying. This is necessary to prepare effective teaching learning programs, and eventually motivate students to engage in learning activities.

Each student must have a different process of thinking, it is possible because of differences in learning styles. According to De Poter \& Hernacki (1999), describes the general human learning style differentiated into three major groups, namely visual learning styles, learning styles auditory, and kinesthetic learning style. Visual learning style is the style of learning by looking, observing, looking at, and the like. Auditory learning style is the style of learning by listening. Individuals with this learning style, more dominant in using the sense of hearing to do learning activities. Kinesthetic learning style is a style of learning how to move, work, and touching. The point is learning by prioritizing the sense of taste and physical movements.

Researchers studied on how to get the great benefits of the information which related this learning characteristics. The reasons are that the findings of the studies will provide significant contributions to develop strategies in improving learning quality. Almost similar with Gunawan (2007) who claimed that students who learnt using their dominant learning styles while sitting in a test will achieve a higher score than when they learn in ways that are not in line with their own 
learning style. In order to achieve the expected learning objectives, teaching learning process have to be compatible with such characteristic.

This study is carried out in referring to the above propositions. It is aimed to identify the student learning styles at Grade V elementary schools in Blitar, East Java Indonesia.

\section{METHOD}

The approach used in this research is quantitative approach. The variable in this study is a single variable, namely the identification of learning styles of grade $\mathrm{V}$ students at elementary schools in Blitar. The population in this study are all students of grade $\mathrm{V}$ elementary schools in the city of Blitar. Simple random sampling was used to select the member of sample. Through this technique, 199 students were selected to be involved in the study. The members of the sample were selected from Elementary School Bendogerit 1, SDI Blitar, SDI Kardina Massa, SD Blitar, SD Kepanjenlor 2 and SD Pakunden 2. The elementary school representatives of the there Districts of Blitar included Sanan Wetan, Kepanjen Kidul, and Sukorejo and represents public schools and private schools in Blitar City.

Learning styles questionnaire was developed from the work of De Poter \& Hernacki (1999) on the three types of learning styles including visual learning styles, learning styles auditory, and kinesthetic learning style. The subject's learning style was revealed using a learning style questionnaire compiled based on the indicators expressed by De Porter. The number of statements in the questionnaire overall learning style that is as much as 36 items and distribution of learning styles questionnaire items, namely on table 1 .

The instrument has been tested by experts and validator has proven its validity and reliability and unfit for use. All statements in the questionnaire are favorable to score Always $=$ 4 , Often $=3$, sometimes $=2$, and Never $=1$ for positive statements, while for negative statements scores Always $=1$, Often $=2$, Sometimes $=3$, and Never $=4$.

Data analysis technique in this research is descriptive statistical analysis method. Questionnaire data obtained from each respondent will be recapitulated based on each learning style. Drawing the conclusions of the trend of learning style by comparing the three values of each question group filled by the subject. Drawing conclusions based on the highest value at a group study style questions, we conclude that subject tends dom inan on the learning style. After that, a recapitulation will be made the percentage of the overall tendency of learning styles of students of class V SD as the city of Blitar.

\section{RESULTS AND DISCUSSION}

Based on the data collected through the instrument of the learning style questionnaire, scores for each research subject or variable were calculated and analysed. Results of the analysis are displayed in Table 2 and Diagram 1.

Table 2 shows that the learning style of elementary school students of Class V in Blitar city $74.37 \%$ or 148 students have auditory learning style, while the kinesthetic learning style $15.58 \%$ or 31 students and 20 students or $10.05 \%$ have a visual learning style.

Table 1. Distribution of Item Questionnaire Learning style

\begin{tabular}{cccc}
\hline \multirow{2}{*}{ Type of Learning Style } & \multicolumn{2}{c}{ No. Problem } & \multirow{2}{*}{ Total Item } \\
\cline { 2 - 3 } & Positive Statement & Negative Statement & \\
\hline Visual & $1,2,3,5,8,10$ & $4,6,7,9,11,12$ & 12 \\
Auditori & $13,15,17,18,19,20$ & $14,16,21,22,23,24$ & 12 \\
Kinesthetic & $25,28,30,31,32,35$ & $26,27,29,33,34,36$ & 12 \\
\hline & amount & & 36 \\
\hline
\end{tabular}

Table 2. Trend of Student Learning Style of Grade V Elementary School in Blitar City

\begin{tabular}{|c|c|c|c|}
\hline No & Learning Styles & Frequency & Percentage \\
\hline 1 & VISUAL & 20 & $10.05 \%$ \\
\hline 2 & AUDITORY & 148 & $74.37 \%$ \\
\hline 3 & KINESTETIC & 31 & $15.58 \%$ \\
\hline & Total & 199 & $100 \%$ \\
\hline
\end{tabular}




\section{GAYA BELAJAR SISWA SD KELAS V DI KOTA BLITAR}

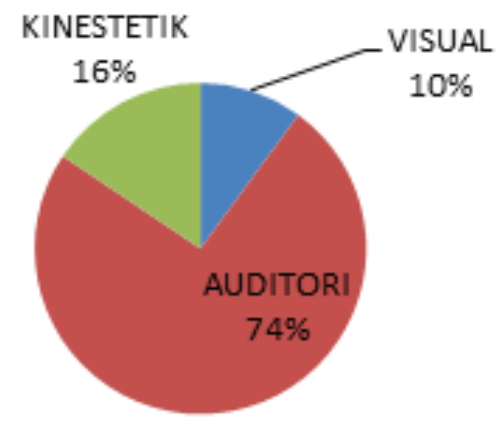

Figure 1. Percentage of Learning Style Trends Elementary Students Class V Kota Blitar Table 3. Trend of Student Learning Style of Grade V Male Elementary School in Blitar City

\begin{tabular}{cccc}
\hline No & Learning Styles & Frequency & Percentage \\
\hline 1 & VISUAL & 13 & $12.6 \%$ \\
2 & AUDITORY & 72 & $69.9 \%$ \\
3 & KINESTETIC & 18 & $17.5 \%$ \\
\hline \multicolumn{2}{r}{ Total } & 103 & $100 \%$ \\
\hline
\end{tabular}

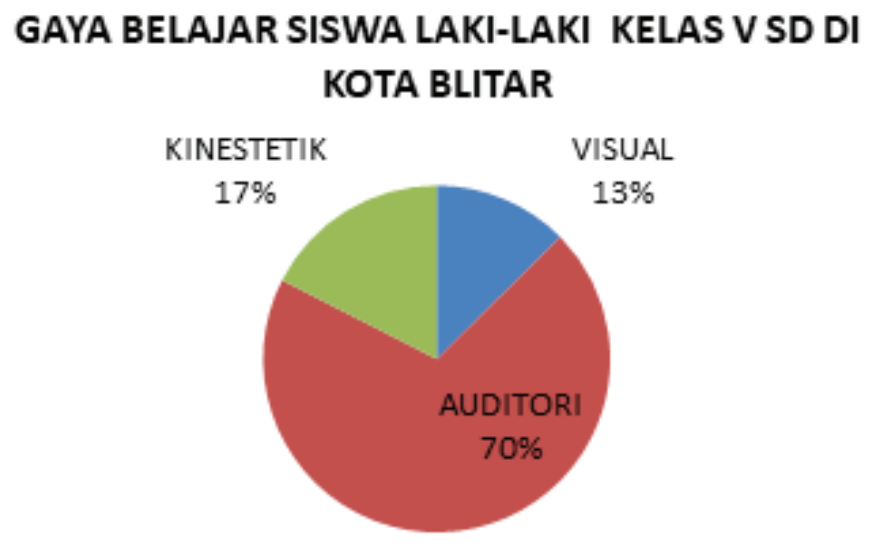

Figure 2. Diagram Percentage of Student Learning Style Trends Men SD Class V in Kota Blitar

Meanwhile, the data of learning styles of male and female students of grade V SD in Blitar city as follows.

Student's learning style male SD Class V in the town of Blitar respectively showed $69.9 \%$ or 72 students have learning styles of auditory, kinesthetic learning style while $17.5 \%$ or 18 students and 13 students or $12.6 \%$ have a visual learning style. Furthermore, served $d$ ata variety of student learning styles in elementary school fifth grade female Blitar city are presented in Table 4.
The variation of learning style of female students of Grade V elementary school in Blitar city showed $79.2 \%$ or 76 students had auditory learning style, $13.5 \%$ or 13 students had kinesthetic learning style and 7 students or $7.3 \%$ had visual learning style.

\section{DISCUSSION}

This study reveals how the learning style of Grade V elementary school students in Blitar City. The first questionnaire instrument validity test conducted by experts judgment. The results 
Table 4. Trend of Student Learning Style of Grade V Female Elementary School in Blitar City

\begin{tabular}{cccc}
\hline No & Learning Styles & Frequency & Percentage \\
\hline 1 & VISUAL & 7 & $7.3 \%$ \\
2 & AUDITORY & 76 & $79.2 \%$ \\
3 & KINESTETIC & 13 & $13.5 \%$ \\
\hline \multicolumn{2}{r}{ Total } & 96 & $100 \%$ \\
\hline
\end{tabular}

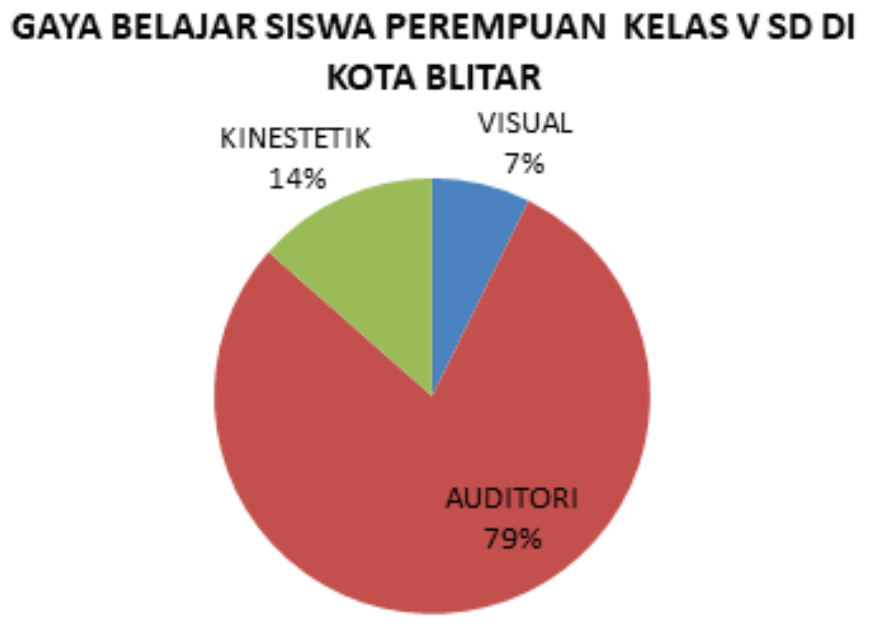

Figure 3. Percentage Diagram Learning Style Trends Female SD Class V students in Kota Blitar

of identification of research instances are questionnaires are grouped based on the tendency of learning styles owned by students by looking at the most tendency scores, then the most tendency is the learning style owned by students. Based on the results of the study with a sample of 199 students gained $74.37 \%$ or 148 students have auditory learning style, 31 students or $15: 58 \%$ have a kinesthetic learning style and 20 students or $10.05 \%$ have a visual learning style. Thus, it can be concluded that the students of grade V SD in Blitar City tend to have an auditorial learning style. The results of this study, in line with Papilaya (2016: 63), that most students have a tendency of auditorial learning style.

The results of this study differ from those of previous studies of the results of the study contained in the National Institutes of Health (NIH) data, US Department of Health \& Human Services (Damayanti, 2012: 2) that in the United States, $20-30 \%$ of school age population considering based on what is heard, $40 \%$ remember through visual (visual) or reading activities. In addition, also with the results of research Iriani (2013: 113) that students class VIII SMPN 2 Kerinci tend to Visual learning style.
Based on the results of research indicate that the dominance of the tendency of learning style of elementary school students of Grade V in Blitar City is auditorial learning style. This is seen from 199 students, 148 or $74.37 \%$ of whom have auditorial learning styles that tend to prefer to learn by listening. This is in accordance with the opinion of Papilaya et al (2016: 7) which states that the auditorial students have difficulty when reading the material when his friends crowded in the classroom, can not concentrate if there is a fuss, can not even focus on learning if there is music that is played with volume big. In addition, it is also in line with De Poter \& Hernacki's (1999) opinion that the auditorial learning style prefers to tell stories but finds it difficult to write, easily distracted by the commotion, can repeat and mimic tones, bars and sound colors, preferring music rather than art, learn by listening and remembering what is being discussed rather than being seen, and likes to talk, discuss, and explain things at length.

Thus, upon learning of the student's learning style of the most dominant then the teacher must prepare se suits their learning style student learning because it can ensure the future of the disciplines of the students. Therefore, 
Sari (2014: 8) states some appropriate learning characteristics for students who are auditory as follows: a) provide information over and over again, can take advantage of these questions; b) use repetition techniques, ask students to recall concepts and instructions; c) teachers use vocal variety in the presentation; d) sing the key concepts or ask students to create a song related to the concept; e) encourage students to make / think "donkey bridges" to make it easier to memorize / remember key concepts; f) use question and answer techniques; g) using question and answer methods, role playing, group work, mnemonics techniques; $h$ ) engage in learning music.

In addition, from the results of the research can be seen that male and female students of grade V SD Blitar City has a dominant tendency in the style of learning auditorial. Looking at the results of this study, the learning styles of male students $(70 \%)$ and female students (79\%) were auditory, suggesting that the dominant stimulation experienced or received by students when studying in grades I to $\mathrm{V}$ was his hearing.

It can be seen from the results of research that boys and girls have the same tendency that auditory learning styles. Results were consistent with the results obtained by Damayanti et al (2012: 88) found that there was no difference in style student learning when viewed in terms of both personality type and type sex. However, the results of this study differ from the results of research conducted by Buali, Balaha \& Muhaidab (2013) resulted in a significant difference in learning styles between male and female students.

\section{CONCLUSION}

Based on the discussion of the findings, it can be concluded that the learning styles of students of grade V SD in Blitar city are sequentially auditory (74\%), kinesthetic (16\%), and visual $(10 \%)$. With regard to students gender, variations of student learning styles in sequence were Auditori (70\%), kinesthetic (17\%), and visual $(13 \%)$. While variations female students' learning styles in order are auditory (79\%), kinesthetic $(14 \%)$ and visual $(7 \%)$. This conclusion lead the researcher to provide suggestions as follow: a) For prospective researchers to perform more optimal research with minimizing those weaknesses is in this study. b) Due to different learning styles will form a different understanding so to achieve maximum learning outcomes, it is expected that teachers need to create learning contexts that are able to involve multi learning styles that could be applied by students individually.

\section{REFERENCES}

Bob Samples. 2002. Revolusi Belajar Untuk Anak. Yogyakarta: Kaifa.

Buali, H. W., Balaha, H. M., Muhaidab, S. N. A. (2013). Assessment of learning style in a sample of saudi medical students. Journal of Acta Inform Medical, 21(2). 83-88.

Damayanti, Andia Kusuma, dan Pratitis, Niken Titi. 2012. Gaya Belajar Ditinjau dari Tipe Kepribadian dan Jenis Kelamin. Persona, Jurnal Psikologi Indonesia September 2012, Vol. 1, No. 2, hal 88-98.

De Poter, B. \& Hernacki, M. 1999. Quantum learning. Yogyakarta: Kaifa.

Gunawan, Adi W. 2007. Genius Learning Strategy. Jakarta: Gramedia Pustaka Utama.

Ilmiyah, Sailatul, dan Masriyah. 2013. Profil Pemecahan Masalah Matematika Siswa SMP pada Materi Pecahan ditinjau dari Gaya Belajar. Jurnal MATHEdunesa. http://jurnalmahasiswa.unesa.ac.id/article/2790/30/article.pdf.

Iriani, Dewi, dan Leni, Mutia. 2013. Identifikasi Gaya Belajar dan Pengaruhnya terhadap Hasil Belajar Siswa pada Materi Kubus dan Balok di Kelas VIII SMPN 2 Kerinci. Prosiding Semirata FMIPA Universitas Lampung, 2013. 109-114.

Papilaya, Jeanetha $\mathrm{O}$, dan Huliselen Neleke. 2016. Identifikasi Gaya Belajar Mahasiswa. Jurnal Psikologi Undip Vol.15 No.1 April 2016, 56-63.

Sari, Ariesta Kartika. 2014. Analisis Karakteristik Gaya Belajar VAK (Visual, Auditorial, Kinestetik) Mahasiswa Pendidikan Informatika Angkatan 2014. Jurnal Ilmiah Edutic Vol.1, No.1.

Sen, Senol, dan Yilmaz, Ayhan. 2012. The effect of learning styles on students'Misconceptions and self-efficacy for learning and performance. Procedia - Social and Behavioral Sciences 46 ( 2012 ) 1482 - 1486. 